\title{
WOMEN AND PRIESTS IN TRACTATE HALLAH GENDER READINGS IN RABBINIC LITERATURE
}

\author{
Cecilia Haendler*
}

\begin{abstract}
This paper examines new possibilities of gendered readings on the relationship between images of priesthood and women in rabbinic texts. It is argued that the ritual of hallah separation, transformed in rabbinic literature from the biblical genderless task into a female domain, emerges as an important element in the substitution of the priests' work. In the absence of a Temple, the newly established rabbinic model of worship sees the act of hallah separation assume a strong imaginative significance, and the figure of the woman who performs it becomes a distinct ritual actor. A gender-sensitive analysis of the sources further exposes the rabbinically instituted rituals as competing with the priestly cult, as well as the ideologies embedded in the text. Moreover, working with such textual material requires the constant reconsideration of scales of values and ideas of hierarchy, in particular those concerning female work and women's rituals, and it underlines the necessity to repeatedly rethinking our gendered methodologies.
\end{abstract}

This article relates to a commentary I am writing on Tractate Hallah in the Mishnah, Tosefta and Yerushalmi, as part of the project "A Feminist Commentary on the Babylonian Talmud" (FCBT). Within this project, different methodological and content-related questions about the ways of applying gender theory and source-criticism to rabbinic texts have been addressed in the last decade. On the one hand, such a work contributes toward the reconstruction of the redactional strategies which formed the rabbinic documents, whereby the application of gender-sensitive analysis opens new avenues for further understanding the composition of the text, and the ideologies underlying its construction. On the other hand, the encounter with this specific material challenges and redefines the methods of feminist and gender analyses themselves, requiring us to reconsider over and over again scales of values and hierarchy (see the analysis below). The intersection in the commentary of textual surfaces as texts using the "marker" women, texts using gender and texts not overtly concerned with gender - whereby gender is at work in their background or the feminine was erased leaving breaches and incoherencies - allows for the discovery of intertextual links, bringing together passages and connections which otherwise would remain undetected.

In the specific case of Tractate Hallah - built on the biblical law stipulated in Num. 15:17-21 about the offering from dough - the content of the treatise requires the consideration of the value attributed to bread-work as ritual work in gender-relevant terms.

In tannaitic sources, as in biblical ones and in the general culture, bread-making is constructed as women's work. However, the biblical text makes of the separation of hallah a genderless task. The ritual, as a solemn ceremony, and the actual domestic preparation of bread with its main actors are ideally separated from one another. The latter is not included in the definition of the law as its primary characterization and staging. The domestic space of everyday bread preparation in this case is left outside religious purpose and ritual significance. However, in the tannaitic text, the opposite takes place: women are constantly referred to as those in charge of carrying out this ritual. We find, for example, female subjects separating hallah within Mishnah Hallah - a short tractate - in 6 mishnayot: Mishnah Hall. 2:3, 2:7, 3:1-3, 4:1. Other (non-neutral) subjects who separate hallah are the baker (nahtom - twice) and a 'man' ('ish-once), whereby all the male subjects are mentioned in mishnayot with women. The central actors of the separation of hallah are thus clearly women. A space 'without sacral meaning' is invested with it. The primarily enfolding-place for the hallah-precept is shifted to, or recognized as, the space of female work.

This can be read as part of a general rabbinic attitude, reflected in the multiplication of ritual "profane" actors. Such a conception stays in ideological tension with the contemporary/preceding world of the Temple and the priests. Within the strategy of constructing the house and the table as substitutes 
for the Sanctuary and the altar (BT Ber. 55a), I argue that female bread-making becomes a key-element for substituting and erasing the priests' work, as well as for recasting the imaginative significance of the "priesthood" in the rabbinic model of worship service.

In this paper, I suggest that bread-making is religiously important for rabbinic Judaism in its forming itself as an alternative for the priesthood's model. The connection between women and the ritual act of hallah-separation established in Jewish practice is thereby significant as well and has a relevant impact on Jewish imagery and self-understanding.

In order to exemplify the reading possibilities sketched thus far I bring different, interacting sources, starting from a textual unit from the Tosefta:

ת' חלה אז

[...] כהן ששייר קמח בעסק' עסתו, וכן אשה ששיירה קמח בעיסתה, הקרץ והשאור מצטרפין לחמשת רבעים לאסר את העיסה

${ }^{2}[\ldots]$

Tosefta Hall. 1:7

[...] A priest who left over some flour in the process of [making] his dough, and likewise a woman who left over some flour in [the process of making] her dough, the crumbs [of dough] and the sourdough combine [with the leftover flour and the batch of dough to comprise] five-fourths [of a qav, the requisite volume imposing liability to hallah], making the dough forbidden [for consumption until one separates hallah from it] [...]. ${ }^{3}$

Here the Tosefta reports a ruling according to which unkneaded flour and dough crumbs that were left over and not yet incorporated into the batch during the process of dough-making, as well as sourdough, concur to the minimum measure obligating the dough to the hallah separation.

The ruling, rather than "generically" and inclusively stated (as it would be in a neutral "one who left over some flour..." שייר קמה - shiyer qemah, or "one who leaves over some flour..." - נשתייר קמח -... - המשייר קמח - ha-meshayer qemah, or in the passive "[if] some flour was left over nishtayer qemah), is conveyed by means of two very specific agents: a priest and a woman - the rabbinic men/authors are excluding themselves from this domain.

The staging of particular ritual actors in the ruling, rather than the use of a more common generic formulation, expresses a metaphorical and ideological undercurrent animating these rabbinic laws. In this passage, the priest and the woman are both described as doing the same activity - making dough - and the same ruling applies to both of them. This doubling of subject is redundant and thus conveys an additional layer of meaning.

We should begin, however, with the question of why the priest should separate hallah? Hallah is one of the gifts that are given to the priests (מתנות הכהונה - matnot ha-kehunah) and could only be eaten by them and by their households (cf. Mishnah Hall. 1:9). Once dough becomes subject to hallah, it is forbidden to eat from it until hallah is separated (cf. Mishnah Hall. 3:1). The halakhic term for such dough, or for produce subject to tithes or terumah prior to their removal, is (teven). According to Sifre Numbers 121 just as an Israelite is forbidden to eat tevel, a priest may not eat it either. Even though priests eat the terumah, ma aser and hallah that will eventually be separated from the tevel, they are not permitted to eat the produce while it is still unseparated. Therefore, if priests purchased untithed produce from a farmer, they must separate the appropriate tithes from it. However the tithes remain in their possession and they eat them, as well as the rest of the produce (cf. Mishnah Peah 1:6). The entire operation seems quite artificial and a rabbinic move to, at least ideally, subjugate the priests to their rulings. They are forcing the priests into a rabbinic frame, trying to "rabbinize" them. The

\footnotetext{
* Institut für Judaistik, Freie Universität Berlin, Germany.

'For the language see Mishnah Pes. 3:4 (שלש נשים עוסקות בבצק - "Three women work with the dough") and T. Pes. 3:8. Saul Lieberman, (ed.), The Tosefta: Order of Zeraim I (New York: Jewish Theological Seminary, 1955), 276.

${ }^{2}$ Vienna MS. The variants in the Erfurt MS are irrelevant for the present discussion.

${ }^{3}$ Gender related parts of rabbinic quotations are underlined in Hebrew and emboldened in the accompanying English translation.
} 
prescribed separation and the prohibition to eat unseparated produce for the priests has a ritual significance in emphasizing that the offering actually belongs to G-d and not to the priestly cast. It is thus permitted to them only when it is separated from the rest of the produce, meaning when it is marked as being directed at the outset toward the Divine. The underlying meaning of these acts is that the offering is granted to the priests for consumption only because of their function in the service of, and subordination to G-d's altar (cf. the concept in BT Men.6b: כהנים משולחן גבוה קא זכו - "the priests receive [the offerings to eat] from the Table of the Most High").

Looking closer at a text in Sifre Numbers 121 another factor emerges:

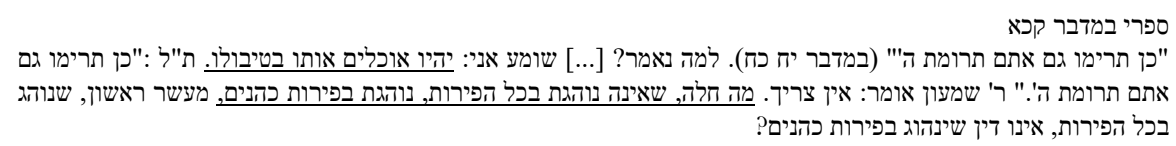

Sifre Numbers 121

Thus shall you, too, separate the terumah of 'ה. (Num. 18:28) Why is this written? [...] I might think that they [the priests] could eat it [the produce] [when it is] tevel [untithed]. It is therefore written: Thus shall you /the priests], too, separate the terumah of 'ה. (Num. 18:28). R. Shime'on says: This [derivation] is not needed, for if hallah, which is not the custom [to separate] from all the produce [cf. Mishnah Hall. 1:1], is the custom [to separate] from the produce of the priests, ma 'aser rishon, which is the custom [to separate] from all the produce, should it not be separated from the produce of the priests?

R. Shime'on derives the obligation for the priests "to separate terumah and ma'aser from tevel before eating the produce" in analogy (היקש - heqesh) to "what is practiced"/"what is the custom" (נהג - nahag) in the case of hallah. The laws of terumah and ma'aser are derived here from those of hallah and not vice versa, as is typically the case. The analogy from the latter to the former in the present case is therefore unexpected. This is because the difference between separating terumah and hallah is a gendered one, whereby tithes, separated in the field, are epitomized as a male domain whereas dough, produced at home, as a female one. Moreover, the origin of the idea that obligates the priests to separate hallah is grounded in a "custom"; neither a rabbinic nor a priestly interpretation or exegesis of this "custom" is available.

The text declares that this practice was not initiated in the study house. Had it been, such origins would not have been negated, since making others depend on rabbinic knowledge represents an important control tool. The first opinion looks for a discursive and interpretative proof for the law in the biblical text. R. Shime'on, however, rejects the need for a scriptural justification of the ruling, because the custom at its origin is considered valid enough.

If so, by whom was the custom of separating hallah from the priests' produce, used by R. Shime'on as halakhic foundation, initiated? There are some examples of מנהג כהנים - minhag kohanim in tannaitic literature, as in Tosefta Kel. B. B. 3:7: "But the priests were accustomed [nahagu kohanim] not to keep bottoms [of baskets] impure" ( טלא שנהגו כהנים שלא יהו מקיימין את הגפיין (טמאין). As pointed out by Furstenberg, in this Tosefta, a conflict between two ways of practice is presented: one is ascribed to the rabbis and one is ascribed to the priests. ${ }^{5}$ The custom of the priests represents an act of resistance against a rabbinic ruling and a competing view on this topic. The text implies that the rabbis offer an alternative solution to the stricter custom of the priests in a problem of impurity. In Tosefta Kel. B. B. 3:4 R. Yehudah reports another priestly use which collides with a rabbinic one "I state a law from the days of the priests" ( כהנים). In Tosefta Yom. 1:9 it is said that those who after the destruction of the Temple observe the priestly custom [nohagin] of not sleeping the eve of Yom Kippur are sinful ( כך היו נוהגין בגבולין

\footnotetext{
${ }^{4}$ An example of priestly exegesis contrasting a rabbinic one can be found in Mishnah Shek. 1:4: "the priests expounded this verse for their own benefit."

Yair Furstenberg, "Eating in the State of Purity during the Tannaitic Period" (PhD diss., The Hebrew University of Jerusalem, 2010), 200 [Hebrew].
} 
(אחר חורבן הבית זכר למקדש אבל חוטאין . These cases show that the minhagim of the priests were not usually assimilated in rabbinic halakhah, but rejected by it. A minhag kohanim reflects indeed either some benefit for the priests and their authority or their interpretation and understanding of Scripture's commandments; all elements the rabbis undermine in a certain measure, in their own interest.

Note, however, that in the case of separating hallah from the produce of the priests, this "anonymous" minhag is not disapproved, but rather used as a source for rabbinic halakhah. Moreover, the character of this law does not in itself seem to be to the advantage of priests. As already pointed out, this custom also does not insist on the act of the priests eating the offerings; rather, the very act of separating an offering and giving it away is emphasized.

In this ruling, one can already see a shift from priestly prestige, prerogative and gain to other concerns, such as the consecration of everyday activities. This development is clear in slightly later sources. The household of R. Yannai [de-vei R. Yannal] "had the custom [nahagin] of offering produce to each other in the field and eating it and not tithing it” (דבי רבי ינאי ואמרין פהגין הוינן (יהבין אילין לאילין בחקלא ואכלין ולא מתקנין (YT Maas. 2:3, 49c). ${ }^{6}$ The act of offering and giving remains, but the priests do not exist as recipients anymore: "Others adopted an innovative way to pay tithing per biblical injunction without actually giving it to the priests - set it apart and destroy it" (YT Shek. $8: 4,51 \mathrm{~b}){ }^{7}$ This practice is already attested in tannaitic literature for the hallah separated outside the Land of Israel. The rabbis also enforced the separation of hallah outside the Land against the plain meaning of the biblical text, while terumah and tithes were not enforced in the Diaspora. This makes hallah exceptional and, justified on the basis of impurity concerns outside Israel, it was decreed that one hallah-portion be separated and then destroyed, and one given to the priest as remembrance $^{8}$ (Mishnah Hal. 4:7-8), whereby later only the portion to be burned remained in force. Mishnah Hallah seems to crystallize an intermediate moment in the fading away of the pries $t$ as recipient of the offering. In general, as Grey notes, "[r]abbinic literature from [the amoraic] period does not emphasize the reception of tithes by priests (it focuses more on the obligation to give tithes)." ${ }^{9}$

Thus, it seems counterintuitive that the priests triggered the law of separating hallah from their produce and that this was a minhag kohanim in its origin, because it underlines the primary importance of the act of separating the offering, regardless of the fact that the priests were those who were entitled to it. It undermines, in a certain measure, their authority and the ranking of their position, levelling their prominence as those who have the prerogative to receive hallah from the other Israelites. The offering is in this view first a ritual act of worship and dedication to G-d, a donation responding to the deep human need to give back and offer something to the Divine.

It seems, therefore, that the rabbis are either imagining priests influenced by a rabbinic practice - namely the infiltration of everyday life into the Temple or in the priestly understanding - or that some sort of impact of accepted beliefs and traditions actually happened, whereby what people do was followed by the priests and then by the study house.

Either way, it can be argued that the anonymous "minhag," the "practice of the people" (to separate hallah from the produce of the priests as well) is likely the practice of women. Women are those primarily involved in bread-preparation and hallah separation, as well as those primarily imagined by the rabbis in this context. Having excluded a priestly or rabbinic exegesis and having

\footnotetext{
"With the term "house of Yannai" also the women of the household are most probably implied and in many rules it can be shown that primarily or only the women of the household are intended. See Tamara Or, Massekhet Betsah (FCBT II/7) (Tübingen: Mohr Siebeck, 2010), $41 \mathrm{ff}$. and Stuart S. Miller, Sages and Commoners in Late Antique Israel: A Philological Inquiry into Local Traditions in Talmud Yerushalmi (Tübingen: Mohr Siebeck, 2006), 378ff. 251.

Matthew J. Grey, "Jewish Priests and the Social History of Post-70 Palestine" (PhD diss., University of North Carolina, 2011),

${ }^{8}$ Yerushalmi, YT Hall. 4:4,60a, states that the portion for the priest was required to be separated as a pedagogic measure, so that the people would not think that a pure, sacred offering was being destroyed and burned (שלא יהו אומרי': ראינו תרומה טהורה נשרפת). The concern is not for the priest's role as recipient of the offering being neglected.

${ }^{9}$ Grey, Jewish Priests, 251.
} 
excluded a priestly minhag based on a priestly understanding, it remains the practice of "those who made bread": principally women. Women mostly prepared bread together in shared spaces, such as courtyards. In everyday life priestly women working together with rabbinic women interacted probably on a daily basis (see the Yerushalmi below on the rabbis imagining this situation). We can consider how the latter hallah-separating while working in common influenced the former, which then brought this rite into the priestly world. The fact that this minhag is not named explicitly as one of women may depend on an erasure strategy, which would not be surprising at all in the mouth of R. Shime'on, a scholar of R. Aqiva, leader of a school of thought generally less inclusive of women. ${ }^{10}$ He would accept the minhag as legally valid, but not recognize its initiators. In the case of bread-making we have various examples of מנהג נשים - minhag nashim (women's custom) influencing the halakhah and being reported in rabbinic literature: "women have the habit [nohagot] of not kneading at the end of a festival day in water which was heated up on the festival day" (היו נשים נוהגות שלא היו לשות במוצאי יום טוב בחמין שהוחמו ביום טוב) (Tosefta Pes. 3:7). Another case reads:

\section{BT Pes. $48 \mathrm{~b}$}

Rav Yosef said: Our women used to bake a kapiza [a measure] at a time during Pesah [since it is easier to prevent small quantities of dough from becoming leavened].

In the case of bread making and the rituals and rulings surrounding it, halakhic decisions are thus often recognized as deriving from women's practice and habits; women being those primarily engaged in these activities." In the case of the minhag in Sifre Numbers it seems that women's involvement in the separation of hallah does not only influence the formation of the halakhah (about hallah and about other tithes as well), but their practices/the imaginings surrounding them are also useful to disenfranchise the priestly authority.

The passage in Sifre Numbers states that hallah is separated from the "produce of the priests." Our Tosefta prescribes to a priest preparing dough what contributes to the amount necessary to separate hallah and makes the dough forbidden for eating without separation. However, even if the Tosefta relies as its background on the ruling in the midrash halakhah, it leaves unexplained why it needs to use the figure of the priest in this context and what it wants to convey by it.

If the Tosefta alludes to the case of priests preparing for themselves bread to consume at home, like any other Israelite, it is peculiar that it mentions specifically a male priest. Maybe it does so in order to underline that priests must separate hallah in profane settings, but this is not convincing in this context because of the structure of the text (see below). The same can be said about the gifts that the priests are entitled to receive and whose consumption is not restricted to the Temple, but to anywhere within the boundaries of the Land of Israel (בגבולין - ba-gvulin). Of these, the following are related to bread: a) the hallah-dough and b) grain or flour of the terumah and terumat ma aser offerings, with which the priests could prepare bread in ordinary settings (Tosefta Hall. 2:9). These gifts are given to both women and men, and may be eaten by priests and their entire household (both adults and minors, both males and females, and their slaves, and their animals).

In this context, it seems unnecessary to use the figure of the male priest vs everyday female bread-making, since also women of the priestly household received these gifts (with which, most

\footnotetext{
${ }^{10}$ See Tal Ilan, Silencing the Queen (Tübingen: Mohr Siebeck, 2006), 125-52.

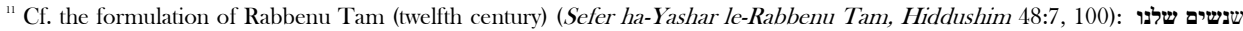
- For our women have the practice to extinguish lights [on Friday afternoon] and then to rekindle them. I saw this myself and asked them and they answered: Yes [this is our practice]. If they themselves are not prophetesses then they are children of prophetesses."
} 
probably, they, and not their men, prepared bread) and ate them. Moreover, both settings (that of the priest and that of the woman) would be ordinary, which creates no contrast between the two figures and a necessity to derive one from the other in the formulation of the Tosefta. By this contrast, the Tosefta seems to refer only to the specific case of a male priest operating where only male priests operate, in specific Temple settings. The priest is described as occupied in making bread and in shaping his dough. No further explanation is given about which sort of dough is intended. However, his title indicates that he is fulfilling a priestly task, or he is representing the priestly caste in particular in regard to this injunction. Likewise, the "woman" prepares her dough: the two figures are staged in the ruling most probably as paradigms for the activity of making bread respectively in the sacra par excellence - the Temple - and in everyday life, which rabbinically must also be sacralised.

There are two additional groups of priestly gifts - beside those that can be eaten everywhere in the Land of Israel - and to which the priestly activities in our toseftan passage might refer. One can only be consumed in Jerusalem (Tosefta Hall. 2:8). The recipient is whatever mishmar, priestly watch, that is on duty in the Temple at that time (Mishnah Bikk. 3:12). These are qodashim qalim: both males and females of a priestly family may eat them. Of these, the ones related to bread are the wheat grain of the bikkurim, out of which the priests, together with their families, could prepare bread for their use, inside Jerusalem. Again the familiar character of this situation seems not to be the case illustrated in our tosefta, which uses the symbolical figure of a male priest.

A last group of gifts - the qodshei qodashim - constitutes the exclusive domain of male priests (as established by Lev. 6:11, 22; 7:6). They can only be eaten by the male priests and only within the walls of the Temple courtyard. Of these, those connected to bread are: the two loaves of bread offered on Shavuot (שתי הלחם - shtei ha-lehem), the showbread (לחם הפנים - lehem ha-panim), the remainder

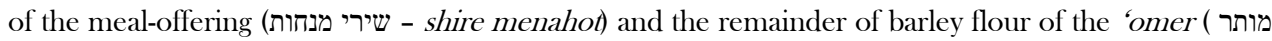
- motar ha-'omer) (Tosefta Hall. 2:7). These are portions that the priests receive from consecrated sacrifices that are offered on the altar. ${ }^{12}$

The activities involved in bread-making are mentioned several times within tannaitic literature in the context of the Temple: a) for the preparation of the voluntary baked meal-offerings (whereby in this case it is not specified who prepares the menahot of bread and cakes, see e.g., Mishnah Men. 5:2, 8); b) for the remainders of the flour minhah (מנחת סולת - minhat solet) with which the priests prepared bread and other baked goods for themselves inside the Temple courtyard, since they could not bring the gifts from such most-holy offerings outside the precincts of the Sanctuary (BT Sot. 14b); c) in the context of the priests producing bread for the Temple (i.e., the showbread and the two Shavuot loaves: Mishnah Men. 11:1-2; Tosefta Men. 11:1), which then they ate inside the Temple's inner court. ${ }^{13}$

The male priest mentioned in our Tosefta could therefore be preparing bread in the Temple from the remainders of the flour minhah or the 'omer; or perhaps the dough he prepares is for the Temple work (for the showbread or the two loaves of breads). However, can it be that the intention here is that hallah be separated from these already sacred products (qodshei qodashim) who belong first and foremost to the altar of G-d? I am not aware of any ruling that states this, even indirectly. It could be that Sifre Numbers refers, with the expression "produce of the priests," not only to the produce a priest acquires unseparated, in ordinary settings, but also to all the priestly gifts, even the most sacred offerings dependent on the altar's sacrifices. However this is not mentioned and it would seem to contradict other halakhic statements. ${ }^{14}$

\footnotetext{
${ }^{12}$ In rabbinic halakhah, the auxiliary menahot (מנחת נסכים - minhat nesakhim) are burnt on the altar in their entirety (Mishnah Men. 6:2).

${ }^{13}$ The lehem ha-panim was prepared by the Levite family of Kehati (1 Chron. 9:32). In tannaitic literature, a family of Kohanim, Beit Garmo, is said to have made the showbread in the Temple (e.g., Mishnah Shek. 5:1, Tosefta Shek. 2:6, Mishnah Yom. 3:11, Tosefta Yom. 2:5,). Mishnah Tam. 3:3 mentions a לשכה שהיו עושין בה לחם הפנים, a Temple's chamber in which the panim bread was made.

${ }^{14}$ Holy offerings are not liable to hallah according to Mishnah Men. 10:4, Mishnah Hall. 1:3 and Mishnah Hall. 3:3.
} 
Because of the uncertainty of the priest's activity depicted here, one could get the impression that the toseftan text models the priest on the woman: the priest is acting like a rabbinic woman. In this case, the woman is the known source and model for the sacred, as experienced in the rabbinic world, whereby, when thinking of a priest making bread in the Temple, the rabbis imagine him separating hallah. It seems that the underlying concept structuring this halakhah is 'the priest as a woman.' This is a metaphorical construction of drawing from the familiar in order to map the less-known.

However, the utilization of וכן ('and likewise') for the figure of the woman implies the contrary, namely, that the ruling for women preparing bread is derived from a ruling established for priests preparing bread in the Temple. This construction intends to convey that a rabbinic ritual has its origin in the Temple. In order to show that the sanctity of the Temple has moved into the rabbinic world, and that the new system of rituals has replaced the Temple rituals, the text uses here the female ritual of separating hallah. In this parallel, the woman represents the rabbis, that is, the Torah world and its continuation with the religious rule of the priests. From the point of view of the authors and redactors, women's bread rituals legitimize the rabbinic system. This creates a "sacred space", which has gained the sacral authority of the Temple.

The fact that this sacra is established in a female workplace, which until now had no specific significance for official, ceremonial religion, does not bother the rabbinic imagination. Here we have the figure at the very top of a different Jewish hierarchy ladder - the priest - and the figure, who is, if not at the very bottom, often pushed much lower on such a ladder - the woman. In this passage, however, the woman outweighs the priest in ritual significance, since she fulfils the ritualization of bread and food preparation in the present, which he, in the absence of the Temple can no longer fulfil. The text seems to suggest that in profane settings women replace the priests, leaving the impression of a strong parallelism between priests and women in the portrayal of bread-making and the cultic rituals associated with it.

The $F C B T$ has raised the issue of the direction of the construction priest/woman. Hannah Tzuberi has advanced the idea that in rabbinic depiction women take over the role of the priests after the destruction of the Temple - whereby in the shift of ritual meaning from the priestly Temple-home to the rabbinic house, supervision is placed in female hands. ${ }^{15}$ Dalia Marx and Natan Margalit have introduced several arguments for the notion that the priests in rabbinic literature are feminized, described as behaving as women in their upkeep of the sanctuary-household, in order to disempower or subsume their task. Dalia Marx speaks of depictions of a "non-masculine" priesthood and has pointed out, for example, the parallel between the Temple (labelled Ha-Bayit - the House) as a domestic, confined space and the home, which is constructed as a feminine sphere.$^{16}$ Marjorie Lehman has further shown how patterns of rabbinic authority and differentiating strategies similarly progress towards women and male priests - using representations of women, as well as representations of contrasting masculinities for the priests and for the rabbis themselves (Mishnah Yom. 2:1-2). ${ }^{7}$

As for the historical question, hinted at above, of whether priestly women separated hallah in place of the priests, creating together with rabbinic women a transmission's bridge between the priestly and rabbinic worlds, there is insufficient textual and external material at our disposal to attempt an answer. However, one can take a "next step" in the analysis: the text of Tosefta Hallah analysed here contains a certain measure of tension, incoherence and breaches.

\footnotetext{
${ }^{15}$ See Christiane Tzuberi, “'And the Woman is a High-Priest': From the Temple to the Kitchen, From the Laws of Ritual Im/Purity to the Laws of Kashrut (Toharot)," in Tal Ilan et al., eds., Introduction to Seder Qodashim (FCBT V) (Tübingen: Mohr Siebeck, 2012), 174ff.

${ }^{16}$ Dalia Marx, Tractates Tamid, Middot and Qinnim (FCBTV/9) (Tübingen: Mohr Siebeck, 2013), 11-15; Natan Margalit, "Priestly Men and Invisible Women: Male Appropriation of the Feminine and the Exemption of Women from Positive Time-Bound Commandments," AJS Review 28 (2004): 303-4

${ }^{17}$ See Marjorie Lehman, "Rabbinic Masculinities: Reading the Ba'al Keri in Tractate Yoma," Jewish Studies Quarterly 22 (2015): $109-36$.
} 
These are splinters of something being constructed and reworked. A priest separating hallah is not a typical cultic activity: this activity is clearly identified with rabbinic women. Through the image of priest and woman separating hallah, we gain an insight on how the rabbinic hallah-ritual acquires its particular contours, and indirect indications of the influence of women's practice in this context. Thus, do "the rabbis draw on feminine images in creating their depiction of the priesthood," ${ }^{18}$ as Dalia Marx has suggested, or vice-versa, is women's representation moulded and acted on the High Priest, as Hannah Tzuberi has proposed ? $^{19}$ The question of whether the figure "woman" is derived from the "priests" or whether the "priests" imagined by the rabbis are constructed on the "woman" model and category, should in my opinion be answered as follows: the rabbinic world recreates the figures "woman" (in the present) and "priests" (in the past) using one category to redefine and rewrite the other. The absence of women in the Temple's priestly upkeep depends on the male priests appropriating any role related to the sacred. The rabbis break down the roles ascribed to the priests, splitting the all-gender-encompassing priest-figure into different functions, which are gendered as female and male. The priestly all-male appropriation is disassembled, creating a larger ritual space for women. At the same time, a space already occupied by women and their practice permits the re-imagination of the priests in the Temple of the past (i.e., it is used as a source for recreating that world) and contributes to re-shaping the entire idea of sacred.

To illustrate this point I present the different variations of a narrative mapping rabbinic values, in which gender plays a key-role:

\footnotetext{
${ }^{18}$ Lehman, "Imagining the Priesthood," 100, n.8.

${ }_{19}$ "[T]he woman in the kitchen is the post-Temple equivalent of the priest in the Temple." Tzuberi, “And the Woman is a HighPriest," 169.
} 


\begin{tabular}{|c|c|c|c|}
\hline ת' סוטה ד ב & ת' סוטה יא א & ת' סוטה יגז & בראשית רבה ס טז \\
\hline 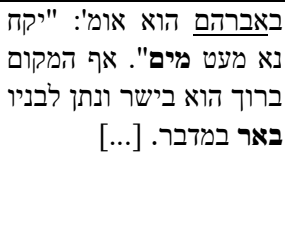 & 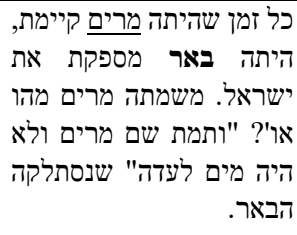 & 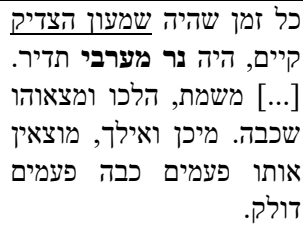 & 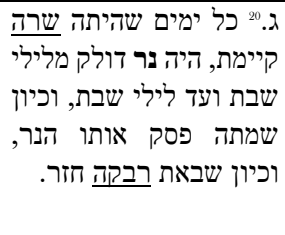 \\
\hline 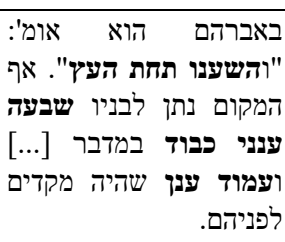 & 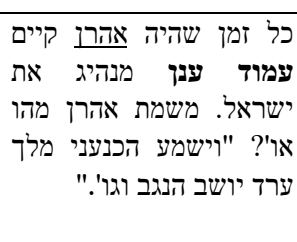 & 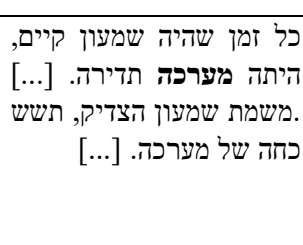 & 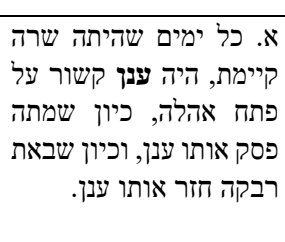 \\
\hline & & & 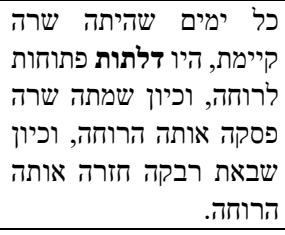 \\
\hline ת' סוטה ד ג & ת' סוטה יא ב & & \\
\hline 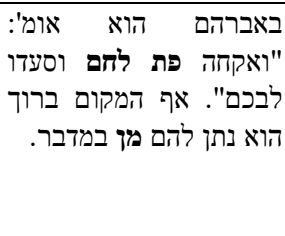 & 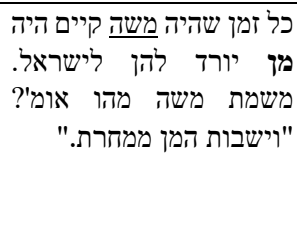 & 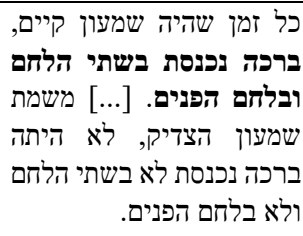 & 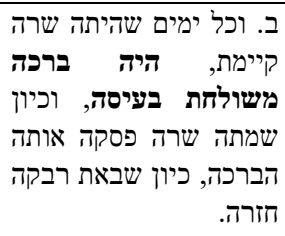 \\
\hline 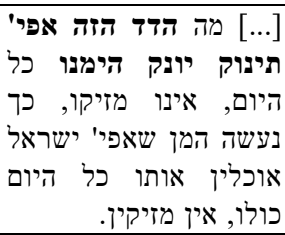 & & & 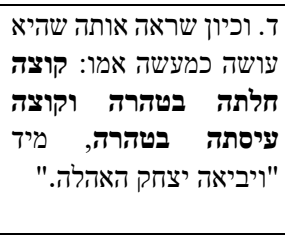 \\
\hline
\end{tabular}

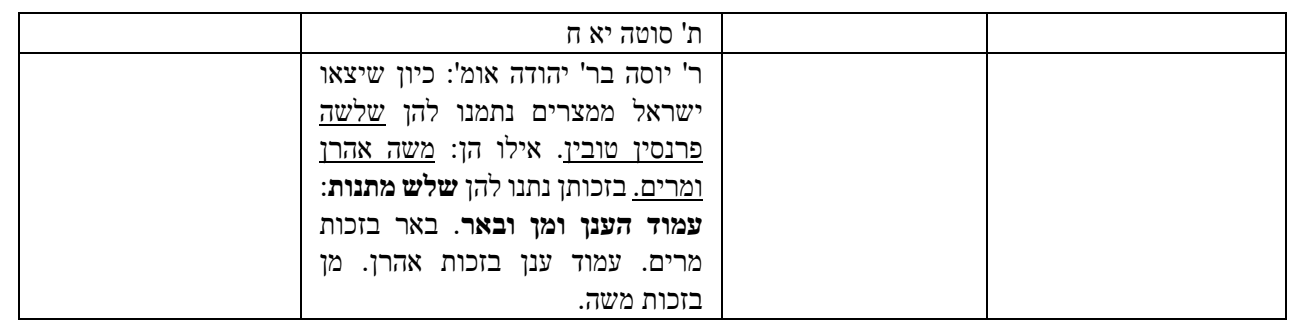

${ }^{20}$ I have inverted the order of the text to better show the parallelism. I have also underlined the parallel people and emboldened the parallel points. 


\begin{tabular}{|c|c|c|c|}
\hline & 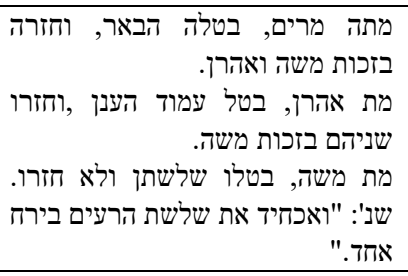 & & \\
\hline Tosefta Sot. 4:2 & Tosefta Sot. 11:1 & Tosefta Sot. 13:7 & $\begin{array}{l}\text { Genesis Rabbah } \\
60: 16\end{array}$ \\
\hline $\begin{array}{l}\text { Of Abraham it is } \\
\text { said: Let a little } \\
\text { water be brought } \\
\text { (Gen. 18:4). So did } \\
\text { the Omnipresent, } \\
\text { blessed be He, } \\
\text { respond graciously } \\
\text { and give to his } \\
\text { children a well in } \\
\text { the wilderness. [...] }\end{array}$ & $\begin{array}{l}\text { So long as Miriam was alive, the } \\
\text { well provided ample water for } \\
\text { all Israel. Once Miriam has } \\
\text { died, what does it say? And } \\
\text { Miriam died there, and there } \\
\text { was not enough water for the } \\
\text { congregation (Num. 20:1-2) - } \\
\text { for the well dried up. }\end{array}$ & $\begin{array}{l}\text { So long as Simeon } \\
\text { the Righteous was } \\
\text { alive the Western } \\
\text { Lamp remained } \\
\text { permanently lit. } \\
\text { [... When he } \\
\text { died, they went } \\
\text { and found it has } \\
\text { gone out. From } \\
\text { that time, } \\
\text { sometimes they } \\
\text { found extinguished and } \\
\text { sometimes lit. }\end{array}$ & $\begin{array}{l}\text { c.) As long as Sarah } \\
\text { was alive, a lamp } \\
\text { burned continuously } \\
\text { from one Shabbat } \\
\text { eve to the next; when } \\
\text { she died, this ceased, } \\
\text { but when Rebecca } \\
\text { arrived, it returned. }\end{array}$ \\
\hline \multirow[t]{2}{*}{$\begin{array}{l}\text { Of Abraham it is } \\
\text { said: And rest } \\
\text { yourselves under } \\
\text { the tree (Gen. } \\
\text { 18:4). So the } \\
\text { Omnipresent gave } \\
\text { his children seven } \\
\text { glorious clouds in } \\
\text { the wilderness, and } \\
\text { the pillar of cloud } \\
\text { went before them. }\end{array}$} & $\begin{array}{l}\text { So long as Aaron was alive, a } \\
\text { pillar of cloud led Israel. Once } \\
\text { Aaron had died, what does it } \\
\text { say? When the Canaanite, the } \\
\text { king of Arad, who dwelt in the } \\
\text { Negev, heard that Israel was } \\
\text { coming (Num. 21:1). }\end{array}$ & $\begin{array}{l}\text { So long as Simeon } \\
\text { the Righteous was } \\
\text { alive, the altar fire } \\
\text { was perpetual. [...] } \\
\text { After Simeon the } \\
\text { Righteous died, } \\
\text { the power of the } \\
\text { altar fire grew } \\
\text { weak. [...] }\end{array}$ & $\begin{array}{l}\text { a.) As long as Sarah } \\
\text { was alive, a cloud was } \\
\text { visible over her tent; } \\
\text { when she died, the } \\
\text { cloud departed but } \\
\text { returned with the } \\
\text { arrival of Rebecca. }\end{array}$ \\
\hline & & & $\begin{array}{l}\text { As long as Sarah was } \\
\text { alive, the doors of } \\
\text { her tent were wide } \\
\text { open; but once she } \\
\text { died, that opening } \\
\text { ceased; but with } \\
\text { Rebecca that } \\
\text { opening returned. }\end{array}$ \\
\hline
\end{tabular}




\begin{tabular}{|c|c|c|c|}
\hline Tosefta Sot. $4: 3$ & Tosefta Sot. 11:2 & & \\
\hline $\begin{array}{l}\text { Of Abraham it is said: } \\
\text { I will fetch a morsel of } \\
\text { bread that you may } \\
\text { nourish your heart } \\
\text { (Gen. 18:5). So did } \\
\text { the Omnipresent, } \\
\text { blessed be He, give } \\
\text { them manna in the } \\
\text { wilderness. }\end{array}$ & $\begin{array}{l}\text { So long as Moses was alive, } \\
\text { the manna came down to } \\
\text { Israel. When Moses died, } \\
\text { what does it say? And the } \\
\text { manna ceased on the } \\
\text { morrow (Josh. 5:12). }\end{array}$ & $\begin{array}{l}\text { So long as Simeon } \\
\text { the Righteous was } \\
\text { alive, the two } \\
\text { loaves and the } \\
\text { showbread were } \\
\text { blessed. [...] But } \\
\text { when Simeon the } \\
\text { Righteous died, the } \\
\text { two loaves and the } \\
\text { showbread were no } \\
\text { longer blessed. }\end{array}$ & $\begin{array}{l}\text { b.) As long as Sarah } \\
\text { was alive, there was a } \\
\text { blessing on her } \\
\text { dough, but when she } \\
\text { died, such blessing } \\
\text { ceased. But, when } \\
\text { Rebecca came, the } \\
\text { blessing returned. }\end{array}$ \\
\hline \multirow[t]{3}{*}{$\begin{array}{l}\text { [...] Just as in the case } \\
\text { of the breast, if a } \\
\text { suckling sucks from it } \\
\text { all day long, it does } \\
\text { not harm [the baby], } \\
\text { so the manna was } \\
\text { made that even if the } \\
\text { Israelites ate it all day } \\
\text { long, it did them no } \\
\text { harm. }\end{array}$} & & & $\begin{array}{l}\text { d.) Isaac saw that } \\
\text { Rebecca acted in the } \\
\text { same manner as his } \\
\text { mother had: she set } \\
\text { aside her hallah in } \\
\text { purity and kneaded } \\
\text { dough in purity. } \\
\text { Immediately (Gen. } \\
24: 67) \text { Isaac brought } \\
\text { her into his mother } \\
\text { Sarah's tent. }\end{array}$ \\
\hline & T. Sot. 11:8 & & \\
\hline & $\begin{array}{l}\text { R. Yose ben Yehudah says: } \\
\text { When the Israelites went } \\
\text { forth from Egypt, three } \\
\text { good providers were } \\
\text { appointed to them. These } \\
\text { are they: Moses, Aaron, } \\
\text { and Miriam. On their } \\
\text { account were three gifts } \\
\text { given to them: the pillar of } \\
\text { cloud, manna, and the well } \\
\text { - the well through the merit } \\
\text { of Miriam. The pillar of } \\
\text { cloud through the merit of } \\
\text { Aaron. And the manna } \\
\text { through the merit of Moses. } \\
\text { When Miriam died, the } \\
\text { well ceased, but it came } \\
\text { back through the merit of } \\
\text { Moses and Aaron. } \\
\text { When Aaron died, the } \\
\text { pillar of cloud ceased, but } \\
\text { both of them came back } \\
\text { through the merit of Moses. } \\
\text { When Moses died, all three } \\
\text { of them came to an end and } \\
\text { never came back, as it is }\end{array}$ & & \\
\hline
\end{tabular}




\begin{tabular}{|l|l|l|l|}
\hline & $\begin{array}{l}\text { said, In one month I } \\
\text { destroyed the three } \\
\text { shepherds (Zech. 11:8). }\end{array}$ & & \\
\hline
\end{tabular}

In the text about Abraham (Tosefta Sot. 4:2-3) the topic is the greatness of the measure of retribution, exemplified by the reward assigned to the legendarily-righteous patriarch for his deeds. The actions considered worthy and deserving in the rabbinic Torah ethos are unfolded in this passage, and they are strongly domestic and nurturing. The hospitality and care Abraham offers to his guests are then given back much more bountifully by G-d to Israel. Abraham supplies the visitors with water, protection, a place of rest under his roof, and bread. These acts have religious significance and are reproduced by G-d with the miraculous well (באר) - source of life -, which He lets spring in the wilderness within the camp of Israel; the glorious pillar of cloud (עמוד ענן) of the Divine presence sheltering, covering and guiding the Israelites; and the wonder of the manna (מן ) which descends from Heaven to feed them. The maternal, nourishing significance of these Divine acts is expressed by the metaphor describing the manna of G-d as breasts for suckling.

In T. Sot. 11:1-2 the protagonists are other biblical characters: Miriam, Aaron, Moses. ${ }^{21}$ They were "good providers" (פרנסין טובין) (Tosefta Sot. 11:8), meaning that, because of their merits Israel received the same three gifts mentioned in the previous tosefta: the well through the merit of Miriam, the pillar of cloud through that of Aaron, and the manna through that of Moses. Note that the well symbolically represents the Torah ${ }^{22}$ (Miriam); the pillar of cloud represents bodily integrity and purity (Aaron, the priests) and the manna represents sustainment, food, bread, blessing (Moses, the leader and sustainer of the people of Israel). Moreover, the se three elements are fundamental for sustaining life. In Tosefta Sot. 11:1-2,8 another component and literal formula is present: "as long as $\mathrm{x}$ was alive, ... / when $\mathrm{x}$ died, y ceased ..." When the righteous uphold the sacred in Israel, G-d stokes the blessing on Israel; when they died, both are extinguished.

The third text (Tosefta Sot. 13:7) introduces one of the two figures of our Tosefta in hallah: a priest, and specifically, the High Priest Simeon the Righteous. The well of the preceding stories is replaced by the western lamp (נר מערבי) permanently illuminating the Temple, as a parallel metaphor representing the inextinguishable source of Torah (BT Sot.21a). The pillar of cloud is replaced by the altar fire and the smoke issuing from it. The manna - the bread of Heaven - by the sacred Two Loaves and the showbread. All the elements of the biblical, mythical past are reproduced in the Temple at the hands of the righteous High Priest. As in the stories on the biblical figures, only when he was alive, the bread was blessed (a hint to the blessing over the domestic bread and the separation of hallah), while the light and the smoke were vivid. However, when he died, all these ceased. The Temple here is modelled on the rabbinic house; the triplet of blessed activities of the High Priest has indeed a certain affinity to the three female commandments. The priest lights the western lamp in the Temple (הדלקת נר התמיד - hadlaqat ner ha-tamid, cf. Mishnah Tam. 6:1), like the woman lights the Shabbat lamp in the house (הדלקת הנר - hadlaqat ha-ner, Mishnah Shab. 6:1). ${ }^{23}$ The cloud and the smoke on the altar, signalizing the Divine presence among Israel, the purity of the priests and a pleasing moment for $\mathrm{G}-\mathrm{d}$, reflect the rabbinic sexual and purity laws, which are the second commandment to which a woman is commanded (niddah). The blessing

\footnotetext{
${ }^{21}$ On the role of Miriam in the traditions where she is listed together with her brothers see Tal Ilan, Massekhet Hullin (FCBTV/3) (Tübingen: Mohr Siebeck, 2017), 418ff., esp. 423 and 'Miriam the prophetess' and 'Miriam's well' in Tal Ilan, Massekhet Ta'anit (FCBT II/9) (Tübingen: Mohr Siebeck, 2008), 135-40.

${ }^{22}$ E.g. see BT Ber. 56b: "One who sees a well in a dream [...] has found Torah, [as the well symbolizes Torah]. As it is stated with regard to the Torah [...]: A well of living waters (Song. 4:15)” (הרואה באר בחלום [...] מצא תורה, שנאמר: [...] "באר מים חיים).

${ }^{23}$ The western lamp was never allowed to go out and BT Shab. 22a states that its burning perpetually was a testimony that the Shekhinah dwells in Israel (כעדות לכך שהשכינה שורה בישראל). This sense of continuity and of the Divine presence dwelling in Jewish abodes is part of the Shabbat-lights metaphorical equipment as well (see, e.g., BT Shab. 23b where Rav Yose compares the kindling of the Shabbat lights by his wife while it is still day with G-d's pillar of fire appearing before the end of the day and the removal of the pillar of cloud; it is an overlapping staying for the uninterrupted presence and protection of G-d. The kindling of the light by his wife ensures such sense of continuation and protection between day and night on the eve of the Shabbat).
} 
on the bread is parallel to the laws of hallah. All three allow the continuation, survival, perpetuation and reproduction of Israel.

Indeed, the fourth text, this time a midrash, Genesis Rabbah 60:16, has Sarah and Rebecca as subjects, who also represent rabbinic women/wives. Here the hospitality attributed in the Tosefta to Abraham is attributed to Sarah ("the doors of her tent were wide open"). Abraham invites the hosts to rest under the tree and so G-d shields Israel with the pillar of cloud: also in the case of Sarah, the cloud which rests on her tent is connected to the openness and reception of her tent. Her lamp of Shabbat (נר שבת) parallels the lamp of the High Priest (her "lamp burned continuously from one Shabbat eve to the next"), and on her dough blessing rests like on the priestly showbread. The fitness of the Jewish wife is then defined by her attending to the laws of the separation of hallah and of making bread in purity, whereby hallah separation is singled out as particularly significant at the end of the text. In this last example, the chain of transmission is not interrupted, as in the preceding ones. Righteousness is newly achieved through everyday ritual exercise; and the work of the priests, their performance of the sacred rites, is achieved through new channels and augmented with new characteristics. As long as rabbinic women keep practicing the "sacred," sustaining the ritualization of the ordinary and performing Torah, the blessing and sustainment of the rabbinic new sanctuary will not cease - as it has in case of the Temple after the death of the righteous High Priest or after the death of the righteous in the biblical past - and continuation is assured. This rhetoric about rabbinic women resembles the idea, according to which the priests' service in the Temple keeps the foundational relationship with the Divine alive and ensures benevolence to the rest of the world.

\begin{tabular}{|l|l|l|l|}
\hline Tosefta Sot. 4:3 & $\begin{array}{l}\text { Tosefta Sot. } \\
\text { 11:1 (and 11:8) }\end{array}$ & Tosefta Sot. 13:7 & Genesis Rabbah 60:16 \\
\hline Abraham & $\begin{array}{l}\text { Miriam, } \\
\text { Aaron, Moses }\end{array}$ & $\begin{array}{l}\text { High Priest Simeon } \\
\text { the Righteous }\end{array}$ & $\begin{array}{l}\text { Sarah, Rebecca, rabbinic } \\
\text { women/wives }\end{array}$ \\
\hline water / well & well & western lamp & c.) lamp Shabbat \\
\hline $\begin{array}{l}\text { rest under the three / } \\
\text { pillar of cloud }\end{array}$ & pillar of cloud & $\begin{array}{l}\text { altar fire / wood / } \\
\text { smoke }\end{array}$ & $\begin{array}{l}\text { a.) cloud } \\
\text { doors of her tent open }\end{array}$ \\
\hline bread / manna & manna & $\begin{array}{l}\text { two loaves and the } \\
\text { showbread were } \\
\text { blessed }\end{array}$ & b.) blessing on her dough \\
\hline breastfeeding & $\begin{array}{l}\text { as long as } x \text { was } \\
\text { alive } \\
\text { when } x \text { died } \\
\text { ceased } \\
\text { came back } \\
\text { never came } \\
\text { back }\end{array}$ & $\begin{array}{l}\text { as long as x was alive } \\
\text { when x died } \\
\text { ceased }\end{array}$ & $\begin{array}{l}\text { d.) she set aside her hallah in } \\
\text { purity and kneaded dough in } \\
\text { purity }\end{array}$ \\
\hline retribution & $\begin{array}{l}\text { as long as x was alive } \\
\text { ceased } \\
\text { came back }\end{array}$ \\
\hline
\end{tabular}

The penetration of the rabbinic paradigm into the priestly system constructed around the Temple of the past, imposing women as active executors in the sphere of the sacred, is exemplified even better by the evolution of the idea proposed by Tosefta Hallah in the Yerushalmi. In the amoraic text it is not the priest, but the Kohenet (a rabbinic neologism indicating mostly the daughter of a Kohen, 
a priest, ${ }^{24}$ who separates the hallah and carries out the role of an intermediary figure between Israel and G-d, between the world of the priests and the world of rabbinic women:

י' חלה ג א, נט ע"א

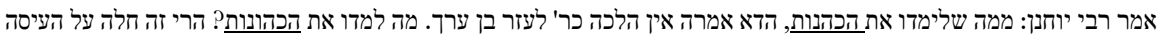

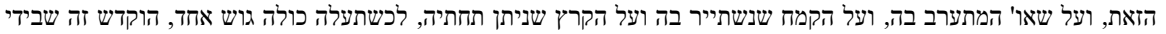
לשם חלה, חוץ מן הטמא שבה.

YT Hall. 3:1, 59a

Rabbi Yohanan said: Based on that which they instructed the kohanot [to declare when separating hallah from others' dough], that tells us that the halakhah does not follow Rabbi Lazar ben Arakh. What was it that they instructed the kohanot [to declare when separating hallah]? "This is hereby designated hallah for this dough [harei zo hallah 'al ha-'issah ha-zot], and for the sourdough mixed into it, and for the flour that remains [unmixed] in it, and for the detached [pieces of dough] that are situated underneath it, when all of it is formed into a single mass, this portion in my hand shall be sanctified as hallah [le-shem hallah], excluding any impure [dough] that might be within it."

This text details how an 'am ha-'arets woman who is unsure about purity laws would have a kohenet to begin the kneading process and to separate hallah for her. Then the kohenet would keep the separate portion of hallah for herself and her priestly household. Indeed, the last sentence, which reads "any impure [dough] that might be within it," demonstrates that purity concerns are at work here.

According to this text, the kohanot prepare dough in a state of purity and separate hallah at the very beginning of the kneading process. At this stage many parts of the flour are still not mixed with water and therefore a specific designation and formulation are required in order to include all the components in the minimum volume necessary for the obligation. The same principle of the Tosefta is here in force (the minimum amount comprises all the parts, sourdough, bits of dough, flour still not completely blended in) and also the same terminology (ועל הקמח שנשתייר בה ועל הקרץ), but the actors are different.

In the Tosefta a male priest is situated in the sacred sphere preparing dough and a woman is in the profane one, while in the Yerushalmi, a priestly woman is depicted carrying out for laywomen the necessary tasks for the sacred. The priestly woman in this role - instead of a priest who biblically carries out every possible task in the Temple and for the sacred activities surrounding it - is invented by the rabbis: we learn about this ritual figure for the first time here. The rabbis project rabbinic women separating hallah onto the Temple's system, bring women in the priestly service and create a female-only sphere of interaction. The imagery of female practice is co-opted to design the cult.

The priestly women are instructed in the halakhah by a rabbinic voice, following the general pattern according to which the priestly actors are made dependent on rabbinic knowledge. ${ }^{25}$ She is thus instructed not because she is a woman, but because she is a priest. We never find a similar formulation ('they were instructed') in cases where hallah is separated by rabbinic women. The verb used to describe the attribution of hallah and other commandments to, or their appropriation by, women is מסר / masar which means "to give, to transmit, to hand down (a tradition, custom)" (Tosefta Shab. 2:10, YT Shab. 2:6, 5b). In Tosefta Shab. 2:10 the verb is used to indicate what bodies of law the 'amei ha-'arets have taken upon themselves, which they have accepted and to which they have contributed. It is worth noting that the kohanot are made experts in a task and incorporated into the rabbinic enterprise by way of learning and ritualization - the rabbinic permutative keys of class and natural order.

In the Yerushalmi, non-rabbinic women are also implied, that is women who do not apply the rules of purity in ordinary settings, but who go to the kohenet to let her perform the ritual in purity for them. As pointed out above, hallah is one of the priestly gifts that the priests and their households may

\footnotetext{
${ }^{24}$ See the excursus on the Kohenet in Ilan, Hullin (FCBT V/3), $565 \mathrm{ff}$.

${ }^{25} \mathrm{Cf}$. the analysis of Yoma by Marjorie Lehman, "Rabbinic Masculinities: Reading the Ba'al Keri in Tractate Yoma," Jewish Studies Quarterly 22 (2015): 112.
} 
consume everywhere and this is probably the setting imagined in this passage. The kohenet separates these offerings in a profane framework, whereby other women bring her their produce to make into dough and/or to be separated very often, or even on an everyday basis. Non-rabbinic women let the kohanot do the rituals for them in the proper way, whereby they recognize the priestly caste as the only group fit to work in purity and in ritual settings in which the sacred is accomplished and executed. This "proper way," however, is rabbinically determined, meaning that the rabbinic customs and laws regulate also the priestly household handling offerings as hallah. Namely, the law of hallah has to be carried out by female actors also in the priestly house or in a sacred priestly space, and women who belong to the rabbinic movements and families - and their daily praxis of separating hallah in purity in lay settings are the model on which the conceptualization of sacred and the priestly functions are regulated.

The rabbis push themselves into the Temple's logic and into the priestly household managing offerings - both of which did not belong to them. Their everyday-sacred model, which shaped rabbinic identity, is made to pervade and invade every sphere, overturning the dependency between the Temple and the street. Other strategies could have been adopted, like the one described by Josephus about the Essenes: priests [iєpeís - iereis] who are elected "for the preparation of their bread and their food" (Ant. 18:22). Here we have a community that acts as priests outside the Temple, bringing the Temple and its logic of exclusivity to permeate everyday life: ordinary meals are treated as holy food consumed by the priests at the Temple; they must therefore be handled in purity and male priests must prepare them. In contrast, in the Yerushalmi, the bread, which must be prepared in purity, is prepared inside the priestly household - as an extension of the Temple's system - by women.

In a text from Qumran ${ }^{26}$ it also seems that - as with Josephus' Essenes and in the case of the women who bring dough to the Temple to be separated there by the priests in purity - the ordinary house is made dependent on the Temple and the priestly caste, to which the sacred is curtailed. According to Joseph Baumgarten, this Qumran passage "identifies [...] חלחם with the loaves (תנופה שתים to be offered on the Festival of Weeks in accordance with Lev 23:17[...]. The text interprets this to refer to an annual terumah, presumably on the basis of the term ראשית (Num. 15:20), which is elsewhere applied to first fruits." Hallah is, according to the Qumran halakhah, offered only once a year, in the Temple. This is strikingly different from the rabbinic halakhah. An offering made once a year - and not from any dough as in the rabbinic legislation - marks the separation of hallah as an exclusive moment - in which the exceptionality of the Temple overrides and trumps the profane - rather than a routine one, which requires a daily or constant interaction, and a different degree of acquaintance, closeness and intimacy with the sacred or the priestly world. In the habitual encounter, distance is replaced with familiarity. This prosaic character is expressed by the Yerushalmi in the following passage:

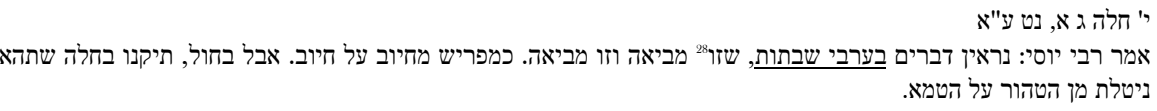

YT Hall. 3:1, 59a

R. Yose said: It appears that the matter [taught above applies] on the eves of the Shabbat [i.e., on Fridays] when this (f.) [woman] brings [her flour to the kohenet] and that (f.) [woman] brings [her flour to the kohenet, in order to have her begin the kneading process and separate hallah from her dough]. [For since there is a large quantity of flour being processed then, the kohenet is] comparable to someone who separates [hallah] from [dough that is] subject [to the obligation].

But during [regular] weekdays [when the total quantity of dough that is brought to the kohenet is generally insufficient to yield a hallah-obligated measure at the time the hallah is separated, the instructions given to the kohanot are not applicable], they instituted regarding the hallah [separated by the kohanot] that it should be taken from pure [dough] on behalf of impure [dough].

\footnotetext{
${ }^{26} 4 \mathrm{Q} 270(4 \mathrm{QD}) 3 \mathrm{ii}, 19-21$.

${ }^{27}$ Joseph M. Baumgarten, “A Qumran Text with Agrarian Halakhah,” The Jewish Quarterly Review 86 (1995): 6.

${ }_{28}^{28}$ MS Moscow, Gunzberg Collection, Nr. 1135; MS Vatican Ebreo 133; ed. Constantinople, year 1662; ed. Amsterdam; MS London, British Library Or. 2822-24.
} 
Here it is imagined that on Fridays the work of the kohanot is different. Friday is indeed the moment when women prepare dough - or more of it than usual - because of the Shabbat, i.e., in order to honour the holy day with fresh bread in abundance and because on the Shabbat itself they cannot bake. This logic has nothing to do with the Temple's inner-working, but rather with the construction of the ordinary week of a rabbinic household. ${ }^{20}$ This gives the impression that between the common house and the House of G-d there is a less hierarchical relationship, indeed almost a mutual reliance is envisioned, where these two poles condition one another; and where the Sanctuary (or the priestly household as a branch stretching out from it) is made contingent upon the pace of rabbinic women. There is also another text in the same section of the Yerushalmi that formulates how the kohenet figure and her sacred work are shaped by the activities of women in rabbinic households:

\begin{abstract}
י' י חלה ג א, נט ע"א
כמפרשת מחיוב על חיוב.

YT Hall. 3:1, 59a

[The kohened is comparable to [a rabbinic woman] (f.) who separates [hallah from dough that is] subject [to the obligation] on behalf of [dough that is] subject [to the obligation].
\end{abstract}

In conclusion, the ultimate model for the separation of hallah is the rabbinic woman. Particularly interesting points include the metaphorical significance and imaginative force of such a structure and how gender and dependency are situated on the spectrum of the association: when women inhabit the source, other people and certain lines of thinking depend on them. This position is part of a broader net of interdependency and this is never unilateral; it has an impact and a voice for the sake of, and because of, this woven fabric. In BT Pes. 50b the biblical תורת אמך - "your mother's Torah" (Prov. 1:8) is understood as signifying custom and practice forming the halakhah. The rabbinic world here shifts ritual and practice significance from the (male) Temple rhetoric to the domestic everyday bread-making. This imaginative non-sacred space, inhabited by women by virtue of an already existing gendered labourdivision, is transformed into a new "sacra." A new ritual actor, absent in the Bible, is created - the woman.

\title{
BIBLIOGRAPHY
}

Baumgarten, Joseph M. “A Qumran Text with Agrarian Halakhah.” The Jewish Quarterly Review 86 (1995): $1-8$.

Cohen, Stuart A. The Three Crowns: Structures of Communal Politics in Early Rabbinic Jewry. Cambridge: Cambridge University Press, 1990.

Furstenberg, Yair. "Eating in the State of Purity during the Tannaitic Period.” PhD diss., The Hebrew University of Jerusalem, 2010 [Hebrew].

Grey, Matthew J. "Jewish Priests and the Social History of Post-70 Palestine." PhD diss., University of North Carolina, 2011.

Ilan, Tal. Silencing the Queen. Tübingen: Mohr Siebeck, 2006.

Ilan, Tal. Massekhet Ta'anit (FCBT II/9). Tübingen: Mohr Siebeck, 2008.

Ilan, Tal. Massekhet Hullin (FCBTV/3). Tübingen: Mohr Siebeck, 2017.

Lehman, Marjorie. "Imagining the Priesthood in Tractate Yoma." Nashim: A Journal of Jewish Women's Studies \& Gender Issues 28, Feminist Interpretations of the Talmud (2015): 88105.

\footnotetext{
${ }^{29}$ Note, however, that a symbolic connection exists, whereby the rabbis state that: "[the showbread] is baked on the eve of the Shabbat" (נאפה בערב שבת) (Mishnah Men. 11:9). Josephus, Ant. 3:10, also reports that: "they [the loaves] were baked on the evening before the Shabbat."
} 
Lehman, Marjorie. "Rabbinic Masculinities: Reading the Ba'al Keri in Tractate Yoma." Jewish Studies Quarterly 22 (2015): 109-36.

Lieberman, Saul, ed. The Tosefta: Order of Zeraim I. New York: Jewish Theological Seminary, 1955.

Margalit, Natan. "Priestly Men and Invisible Women: Male Appropriation of the Feminine and the Exemption of Women from Positive Time-Bound Commandments.” AJS Review 28 (2004): 297-316.

Marx, Dalia. Tractates Tamid, Middot and Qinnim (FCBTV/9). Tübingen: Mohr Siebeck, 2013.

Miller, Stuart S. Sages and Commoners in Late Antique. Israel: A Philological Inquiry into Local Traditions in Talmud Yerushalmi. Tübingen: Mohr Siebeck, 2006.

Or, Tamara. Massekhet Betsah (FCBT II/7). Tübingen: Mohr Siebeck, 2010.

Schlesinger, Simon Solomon. ed. Sefer ha-Yashar le-Rabbenu Tam, Hiddushim. Jerusalem, 1959.

Tzuberi, Christiane. "'And the Woman is a High-Priest': From the Temple to the Kitchen, From the Laws of Ritual Im/Purity to the Laws of Kashrut (Toharot)," in Tal Ilan, Monika Brockhaus, and Tanja Hidde, eds., Introduction to Seder Qodashim (FCBTV), 167-75. Tübingen: Mohr Siebeck, 2012. 